From what has preceded, it may be concluded that the atmosphere contains a hitherto undiscovered gas with a characteristic spectrum, heavier than argon, and less volatile than nitrogen, oxygen, and argon; the ratio of its specific heats would lead to the inference that it is monatomic, and therefore an element. If this conclusion turns out to be well substantiated, we propose to call it "krypton," or "concealed." Its symbol would then be $\mathrm{Kr}$.

It is, of course, impossible to state positively what position in the periodic table this new constituent of our atmosphere will occupy. The number $22.5 \mathrm{I}$ must be taken as a minimum density. If we may hazard a conjecture, it is that krypton will turn out to have the density 40 , with a corresponding atomic weight 80 , and will be found to belong to the helium series, as is, indeed rendered probable by its withstanding the action of red-hot magnesium and calcium on the one hand, and on the other of oxygen in presence of caustic soda, under the influence of electric sparks. We shall procure a larger supply of the gas, and endeavour to separate it more completely from argon by fractional distillation.

It may be remarked in passing that Messrs. Kayser and Friedlander, who supposed that they had observed $\mathrm{D}_{3}$ in the argon of the atmosphere, have probably been misled by the close proximity of the brilliant yellow line of krypton to the helium line.

On the assumption of the truth of Dr. Johnstone Stoney's hypothesis that gases of a higher density than ammonia will be found in our atmosphere, it is by no means improbable that a gas lighter than nitrogen will also be found in air. We have already spent several months in preparation for a search for it, and will be able to state ere long whether the supposition is well founded.

\section{LYON PLAYFAIR.}

$\mathrm{I}^{\mathrm{T}}$ is now fifty-three years since I first met Playfair. $\mathrm{He}$ was President of the Chemical Section of the British Association in 1855 at Glasgow. Frankland and I were the Secretaries. Liebig attended the meeting, and stayed with his friend Walter Crum, and it was appropriate that Playfair, who was one of Liebig's most promising English pupils, should preside over a meeting of chemists at which his German master was present. Playfair then was in the height of his activity. His addresses in 1855 , and again thirty years later, when he was President of the Association, although not containing much of striking originality, were clear, luminous expositions, as indeed were his speeches in the House of Commons, and latterly in the House of Lords.

In the year 1834 , when he was fifteen years of age, he began to study chemistry under Graham, who was then professor at the Andersonian at Glasgow. After a short visit to his parents in India, where his father was Chief Inspector-General of Hospitals in Bengal, he followed Graham to London, and in $183_{3} 8$ went to Giessen to study under Liebig, then the rising star in the chemical firmament. There he became not only Liebig's pupil, but his friend; he worked at organic chemistry, publishing in $184 \mathrm{I}$ his first paper on a new fatty acid contained in the butter of nutmegs, and in the following year he published an abstract of Liebig's report on organic chemistry as applied to chemistry and pathology. On his return to England, through Liebig's influence with James Thomson, a man who even in those early days saw the value of science as applied to industry, Playfair was appointed as chemist to the well-known calico printworks at Clitheroe. After a few years he exchanged this position for a more suitable one in the Royal Institution, Manchester, where he found more congenial society in the friendship of Dalton and Joule. It was

$$
\text { NO. I 493, VOL. 58] }
$$

whilst he was in Manchester that Playfair induced Bunsen, who had just perfected his process of gas analysis, to come over to Alfreton to collect the gases of the blast furnace. The results of this visit furnished the first evidence concerning the chemical changes oc. curring in the blast furnace, and were published in the British Association Reports for I 845 .

It was in conjunction with Joule that Playfair's name is best known as an investigator, several memoirs on atomic volume and specific gravity appearing in their joint names in the Chemical Society's Journal, the most important result of which was the discovery of the wellknown laws relating to the disappearance of the volume of the acid and of the base of crystals of hydrated salts. If Playfair had remained under the influence of Dalton and Joule, his record of original work would probably have been much longer than it is, but his activity was destined to be turned into other channels. Sir Robert Peel, who had heard of Playfair and formed a high opinion of his powers, appointed him on a Commission to inquire into the sanitary condition of large towns, and such matters he found more to his taste than purely scientific research. In recognition of the services which he performed on this Commission, he was appointed chemist to the Museum of Practical Geology. It was here that he carried out his best-known research, namely that on the nitro-prussides, a new class of salts characterised by giving a splendid purple colour with alkaline sulphides. A year or two later preparations were being made for the first great exhibition of $185 \mathrm{I}$, and Lyon Playfair was chosen as a competent man to visit the manufacturing districts to secure the co-operation of persons interested in manufactures and commerce. This somewhat difficult task he accomplished with tact and success, and later on he took a leading part in the classification and arrangement of the exhibits, and the appointment of the juries was mainly left in his hands. A good story is told of his savoir faire at the opening of the exhibition, where it was of course desirable to have all nations represented. A very gaily-dressed Chinaman found himself in the procession side by side with the Archbishop of Canterbury, and was about to be removed to some less conspicuous position when the Prince Consort desired he might be left where he was. Playfair's efforts had been successful in obtaining the recognition of China, for, in the absence of any yellowjacketed mandarin as ambassador, Playfair had got hold of a Chinese ticket-collector of a junk then being exhibited in the docks. Not only during the existence of the exhibition, but even up to the present time, Playfair left his mark on the results of that exhibition, for he was the guiding hand in the numerous and complicated transactions which have taken place since the purchase of the South Kensington Estate by the Royal Commissioners. The foundation of the Science Scholarships, which are now proving such a boon to the aspirants to scientific fame, was entirely Playfair's idea. Working in connection with the exhibition of $185 \mathrm{I}$ brought him into personal contact with the late Prince Consort, in whose household he accepted a post, and it was to Playfair that the Prince was much indebted in his various schemes of land improvement and other scientific matters. A few years later, when the Science and Art Department was put upon a new footing, Playfair was appointed joint secretary with Sir Henry Cole ; this partnership, as might be foreseen from the character of the two men, did not last long, and Playfair became Inspector-General of Government Museums and Schools of Science. A more permanent and satisfactory position was, however, now open to him. In 1856 he succeeded Gregory as Professor of Chemistry in the University of Edinburgh, and in this position he remained for thirteen years, and the wags said that he was the only Scotchman who, having tasted the flesh-pots of Egypt, 
was ever known to return to the land of cakes not plum -but oats.

As I)avy's greatest discovery was Faraday, so it may be said that Playfair's was Dewar, who acted for some time as his assistant. The five months' duties of the Edinburgh chair did not by any means exhaust his energies. On the occasion of the second great exhibition of 1862 , his services were again called for, and in 1868 he was returned to Parliament in the I.iberal interest as representing the Universities of Edinburgh and St. Andrews, a seat which he held for seventeen years. His Parliamentary labours were arduous and important, and his name will go down as representing the reorganisation of the Civil Service. He also presided over many important Committees and Royal Commissions ; indeed, it may be said that for many years no official inquiry was considered satisfactory without the advice of Playfair, whose clear head and common sense were always readily placed at the service of the nation. He was Postmaster-General in Gladstone's ministry of 1873 , and on the return of the Liberals to power in 1880 he was elected Chairman of Ways and Neans, a post which in those stormy days was no sinecure. At the election of 1885 , finding his Liberal views did not coincide with those of the University constituencies, he offered himself as a candidate for South Leeds, and was returned also in 1886 and 1892 . $\mathrm{He}$ was Vice-President of the Council during Mr. Gladstone's short administration of $\mathrm{r} 886$, but was not offered office in 1892, but received the honour of a peerage, which was given him more for his political than his scientific eminence. Playfair was the last remaining original member of the Chemical Society. The banquet which was to have been given in his honour and in that of the other past presidents of fifty years' standing has had to be postponed owing to his somewhat sudden death.

It is to him that we owe the first movement with regard to technical instruction, and his name will go down to posterity as one "who loved his fellow men."

$\mathrm{He}$ was laid to rest at St. Andrews, the city from which his family sprang. His merit was recognised by representatives of the Queen and of the Prince of Wales, and numerous friends and admirers, both scientific and political, as well as by the citizens of St. Andrews.

H. E. R.

\section{OSBERT SALVIN, F.R.S.}

RNITHOLOG Y and entomology have sustained a great loss by the death of Mr. Osbert Salvin, which occurred on the Ist inst. at his beautiful residence Hawksfold, near Haslemere. The second and only surviving son of the late $\mathrm{Mr}$. Anthony Salvin, the wellknown architect, he was born in 1835 , and received his education at Westminster and Trinity Hall, Cambridge, where he graduated as a Senior Optime in the Natural Science Tripos of 1857 . Immediately after taking his degree he, together with Mr. W. H. Hudleston (then Simpson), joined Mr. (now Canon) Tristran in his natural history exploration of Tunis and Eastern Algeria, where they passed five months. In the autumn of the same year Mr. Salvin proceeded to Guatemala, where, chiefly in company with the late Mr. (j. L. Skinner, the celebrated collector of orchids, he stayed till the middle of 1858 , returning to Central America (henceforth always to be associated with his name) about twelve months later. He again went out in 1861 , accompanied by Mr. Frederick Godinan, and continued the explorations he had already begun, but was home again in 1863 . In 1865 he married Caroline, the daughter of W. W. Maitland, Esq., of Loughton in Essex, and with her subsequently undertook another voyage to Central America. In 1874 , on the foundation of the Strickland Curatorship in the Lniversity of Cambridge, he accepted that office, which he filled until $188_{3}$, when, on his father's death,

$$
\text { NO. } 1493 \text {, VOL. } 58 \text { ] }
$$

he succeeded to the property at Hawksfold, and removed thither, though there was scarcely a week in which he did not pass some days in London; for with Mr. (jodman he had conceived the idea of bringing out a "Biologia Centrali Americana," being a complete natural history of the countries lying between Mexico and the Isthmus of Panama. This grigantic task, by far the greatest work of the kind ever attempted, taxed all their united efforts, and those of the many contributors they enlisted, and is still in progress. Before beginning this, Mr. Salvin had edited the third series of the Ibis, of which he was one of the founders, and had brought out a "Catalogue of the Strickland Collection "in the Cambridge Museum. He contributed also the Trochilide (Humming-birds) and Proccllariida (Petrels)-on which he was the acknowledged authority - to the British Museum "Catalogue of IBirds," and almost his latest labour was that of completing and arranging the late Lord Lilford's "Coloured Figures of British Birds"; while the Royal Society's "Catalogue of Scientific Papers" enumerates forty-seven published by Mr. Salvin alone, twenty-three by him and Mr. Godman jointly, and fifty-four by him and Mr. Sclater--all before 1884 .

Mr. Salvin was a Fellow of the Royal, Linnean, Znological and Entomologrical Societies, on the Councils of each of which he frequently served; and it may be truly said that there were few naturalists whose opinion was more often sought, for his advice was generally sound. His figure was well known at the Athen:eum Club, and last year he was elected an Honorary Fellow of his old College. He will be greatly missed by a large circle of friends, to whom his quiet and unassuming manners greatly endeared him.

$\mathrm{N}$.

\section{NOTES}

THE freedom of the city of Edinburgh is to be conferred on Lord Iister on June 15.

THE annual ladies' conversazione of the Royal Society was held yesterday, as we went to press.

THE l'rince of Wales will open the new buildings of the University Extension College, Reading, on Saturday next, June II.

A FloRAI fête and children's fioral parade will be held in the gardens of the Royal Botanic Society, Regent's Park, from 2 to 7 o'clock to-morrow (Friday).

THE city of Como, the birthplace of Alexander Volta, is preparing to worthily celebrate in $\mathbf{1} 899$ the hundredth anniversary of the invention of the Voltaic or Electric l'ile. To commemorate this important event, which has led to some of the greatest discoveries of the present century, there will be held at Como, from May $5_{5}$ to October 15 , an International Electrical Exhibition, to which will be annexed a national exhibition of the manufacture of silk- a branch of trade much developed in Como-and an international exhitition of the machinery, pre. paration, and process of working the same. Italian and foreign electricians are invited to a Congress, which will be held for the purpose of discussing the progress and applications of electricity. Como is a fourishing city on the main line of St. Gothard, and forty kilometres from Milan. It is pleasantly situated at the foot of the Rhaetian Alps, and on the shores of the most beautiful lake of Lombardy, to which it gives its name. An electrical exhibition ought to succeed in Italy, where the abundant hydraulic power greatly facilitates electric works. The application of electricity to the manufacture of silk must be of interest in Como, where the silk.works are of ancient date, and rapid progress is being made, though the industry is indebted to foreign countries for the machinery and implements. We are informed that foreign inventions will be greatly valued at the 